\title{
Impact assessment of the introduction of Cichla kelberi in a large Neotropical reservoir and its lateral lagoons (Upper Paraná River Basin, Brazil)
}

\author{
M. Ferrareze ${ }^{a *}$ and M. G. Nogueira ${ }^{b}$ \\ anstituto de Biociências, Letras e Ciências Exatas, Universidade Estadual Paulista - UNESP, \\ CEP 15054-000, São José do Rio Preto, SP, Brazil

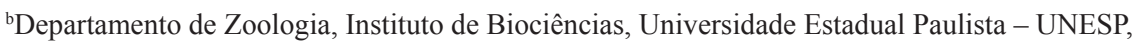 \\ CP 510, CEP 18610-000, Botucatu, SP, Brazil \\ *e-mail: mferrareze@ibb.unesp.br
}

Received: April 10, 2014 - Accepted: July 3, 2014 - Distributed: November 30, 2015

(With 6 figures)

\begin{abstract}
This study aimed to understand how the introduction of Cichla kelberi in Rosana Reservoir (Paranapanema River) affected the native ichthyofauna. Data on the structure of the small fish fauna assemblage were obtained before and after the introduction of this carnivorous species. Samplings were carried out in February and September of 2004, previously to the register of Cichla kelberi in the reservoir, and after its introduction, November of 2004, January, March, May and August of 2005, February and June of 2006, February and July of 2007, February and October of 2008 and February of 2009. A total of 4,693 fish, belonging to 43 different species was sampled between 2004 and 2009. The order Characiformes was the most abundant, followed by Perciformes and Siluriformes. Comparative analyses, before and after the introduction, could not demonstrate significant changes in composition, richness, abundance, biomass, mean length and diversity of fish. Aquatic insects were the main feeding item of C. kelberi, followed by tetragonopterinae fish. Cannibalism was recorded during the whole study period. The results showed that Cichla cannot deeply affect the ichthyofauna assemblages of a large Neotropical reservoir, at least in a short or medium term period after its introduction. The results also allowed concluding that the introduction of $C$. kelberi in the reservoir is in the phase 3. In this phase, the specie can survive and reproduce in the new environment; however it is not totally established and disseminated. The reasons for the fact that Cichla is still not dominant in Rosana Reservoir could be related to feeding competition, high rate of cannibalism and the presence of large amount of aquatic macrophytes (refuge zones). In spite of the results, the continuous monitoring of the role of non-native species on the local fish fauna is absolutely necessary because the impacts caused by colonization of this undesirable species can be magnified by complex processes, usually correlated with other environmental disturb, especially the negative effects of damming.
\end{abstract}

Keywords: Paranapanema River, Rosana reservoir, non-native fish, biodiversity, ecological impact.

\section{Avaliação do impacto da introdução da Cichla kelberi em um reservatório Neotropical de grande porte e suas lagoas laterais (Bacia do Alto Paraná, Brasil)}

\begin{abstract}
Resumo
O objetivo deste estudo foi entender como a introdução da Cichla kelberi no reservatório de Rosana (rio Paranapanema) afeta as assembléias de peixes. Dados da estrutura da ictiofauna de pequeno porte foram obtidos antes e após a introdução dessa espécie carnívora. As coletas foram realizadas em fevereiro e setembro de 2004, quando Cichla kelberi, ainda não havia sido registrado no reservatório, e após sua presença, em novembro de 2004, janeiro, março, maio e agosto de 2005, fevereiro e junho de 2006, fevereiro e julho de 2007, fevereiro e outubro de 2008 e fevereiro de 2009. Um total de 4693 peixes, pertencentes a 43 espécies foi amostrado entre 2004 e 2009. A Ordem Characiformes foi a mais abundante, seguida por Perciformes e Siluriformes. Análises comparativas, antes e depois da introdução, não demonstraram mudanças significativas na composição, riqueza, abundância, biomassa, comprimento médio e diversidade dos peixes. Insetos aquáticos constituíram no principal item da alimentação de Cichla kelberi, seguido por peixes tetragonopterídeos. Canibalismo foi registrado durante todo o período de estudo. Os resultados mostraram que Cichla não afeta substancialmente a ictiofauna dos reservatórios neotropicais, pelo menos no curto e médio prazo após sua introdução. Os resultados também permitiram concluir que a introdução de Cichla kelberi se encontra na fase 3. Nessa fase, a espécie pode sobreviver e reproduzir no novo ambiente, contudo ela não está totalmente estabelecida
\end{abstract}


e disseminada. As razões que explicam a ausência de dominância de Cichla no reservatório de Rosana podem estar relacionadas à competição alimentar, a alta taxa de canibalismo e grande quantidade de macrófitas aquáticas (zonas de refúgio). Apesar dos resultados, o monitoramento contínuo do papel das espécies não nativas sobre a ictiofauna local é de extrema importância, pelo fato de que os impactos causados por essas espécies podem ser amplificados, geralmente correlacionados com outros distúrbios ambientais, principalmente efeitos negativos do barramento.

Palavras-chave: Rio Paranapanema, reservatório de Rosana, peixes não nativos, biodiversidade, impacto ecológico.

\section{Introduction}

River regulation represents one of the major impacts on fish fauna and can drastically change the species composition and abundance. Some species cannot survive to the newly created environment while others can become excessively abundant (Ahearn et al., 2005; Agostinho et al., 2008).

Another serious damage for the ichthyofauna is the introduction of non-native species. The introduction of non-native fish species can cause the decline or even the extinction of native fish populations, the biotic homogenization - the replacement of endemic native species by widespread distributed exotic species (Gido and Brown, 1999; Olden and Poff, 2004; Marchetti et al., 2006; McKinney, 2006; Smith, 2006; Light and Marchetti, 2007).

Biotic invasion, as a consequence of human activities, is an over century phenomenon (Simberloff, 2003). Since the Roman Empire, introduction of fish into alien environments have been mediated by boat displacement, importation of aquarium fish, aquaculture activities based on exotic species, releases for biological control, releases for fisheries improvement, construction of inter-catchment canals for water transportation, pipes and tunnels (Ruesink, 2005; Brasher et al., 2006; Jeschke and Strayer, 2006; Stohlgren et al., 2006). Exotic fishes are positively associated with man-made reservoirs, generally due to stocking for sport fishing and inundation of natural barriers, such large waterfalls (Pringle et al., 2000; Leprieur et al., 2006). Above dam populations of exotics usually have higher abundance than the ones living below dam (Holmquist et al., 1998).

In the last years the introduction of the Amazonian peacock-bass species (Cichla spp.) in Neotropical reservoirs has been considered as a major problem (Kullander and Ferreira, 2006). Cichla is an exceptionally voracious predator and studies showed that its introduction may seriously threat the native fish, compromising the assemblage diversity or even causing the complete regional extinction of several species (Zaret and Paine, 1973; Godinho et al., 1994; Santos et al., 1994; Latini and Petrere Junior, 2004; Pelicice and Agostinho, 2009).

Nevertheless, quantitative analysis of the dispersion and establishment of non-native fish in a wide spatial and temporal scale is still rare. The complete understanding of the process is crucial for prediction, and maybe the avoidance, of further expansion of invasive species and biotic homogenization in aquatic ecosystems (Han et al., 2008).

The proposal of the present study is to evaluate the potential negative impact of the introduction of Cichla kelberi Spix and Agassiz, 1831 in Rosana Reservoir, Paranapanema
River. The aim is to understand how Cichla affects the small size ichthyofauna, comparing the assemblage structure before and after (in a relatively long term) the introduction.

Additional information on the small size fish assemblage distribution and ecological attributes and limnological characteristic of the study environment is provided by Ferrareze and Nogueira (2011) and Ferrareze et al. (2014), respectively.

\section{Material and Methods}

\subsection{Study area}

The study area is located in the upstream (tail) zone of Rosana Reservoir, approximately $80 \mathrm{~km}$ above dam (Figure 1), which is located at $22^{\circ} 36^{\prime} \mathrm{S}$ and $52^{\circ} 52^{\prime} \mathrm{W}$. The reservoir is the last one, from a series of eleven along the Paranapanema River (SP/PR, Brazil), with a surface area of $276 \mathrm{~km}^{2}$ (watershed of $11,000 \mathrm{~km}^{2}$ ), water retention time of 21 days (annual mean values), shallow (maximum of $26 \mathrm{~m}$ close to the dam) and oligo-mesotrophic (Nogueira et al., 2006).

The climate is subtropical humid (average temperature of $21^{\circ} \mathrm{C}$ ) with two pronounced seasons, a dry weather predominates from April to August (autumn/winter), and the rains are concentrated in late spring and summer (from November to March) (Ferrareze et al., 2014).

\subsection{Samplings and laboratory analyses}

The samplings were carried out in February and September of 2004, previously to the register of Cichla kelberi in the Rosana Reservoir (Casatti et al., 2003; Pelicice et al., 2005), and in November of 2004 (register of the first occurrence of this species) (Pelicice and Agostinho, 2009), January, March, May and August of 2005, February and June of 2006, February and July of 2007, February and October of 2008 and February of 2009.

The study was carried out in 4 lagoons and one sampling station in Paranapanema River (PR), close to the river bank (Figure 1; Table 1). Two kinds of lagoons were assessed: 3 natural lagoons and one originated by the flood of mining digging (FPA). The natural lagoons (FPB and FPD) are located inside the State Park of Morro do Diabo, while the last one (FPC) is located in an area influenced by human activities (agriculture and cattle breeding). The dominant macrophytes of each lagoon, in terms of stand area, were registered (Table 1). Identification of these plants was performed at the genus level, with help of taxonomists of Botany Department from Biosciences Institute of State University of São Paulo, UNESP, Campus of Botucatu. 


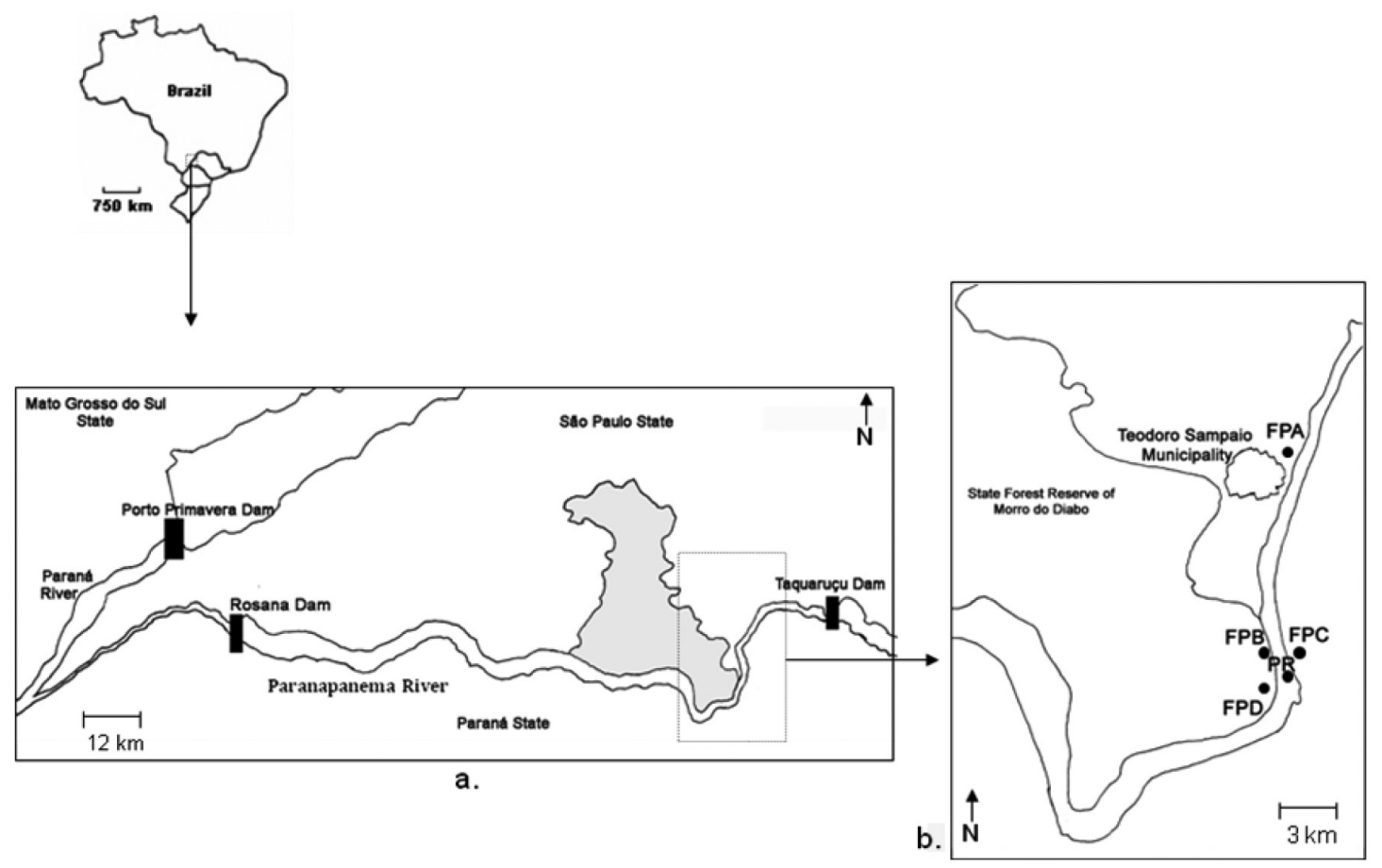

Figure 1. Study area in the region of the confluence of Paraná and Paranapanema Rivers showing the positioning of Rosana, Taquaruçu and Porto Primavera dams and the State Park of "Morro do Diabo" (gray area) (a). On the right (detail) the location of the sampling stations and the municipality of Teodoro Sampaio (b).

Table 1. Denomination of the sampling stations, geographical positioning, lagoons surface area, and main aquatic macrophytes found in each sampling site.

\begin{tabular}{|c|c|c|c|}
\hline $\begin{array}{l}\text { Sampling } \\
\text { station }\end{array}$ & Geographical coordinates & $\begin{array}{l}\text { Area } \\
\left(\mathbf{k m}^{2}\right)\end{array}$ & Dominant macrophytes \\
\hline $\begin{array}{l}\text { Lateral lagoon A } \\
\text { (FPA) }\end{array}$ & $22^{\circ} 34^{\prime} 03.3^{\prime \prime} \mathrm{S} / 52^{\circ} 09^{\prime} 11.4^{\prime \prime} \mathrm{W}$ & 0.110 & $\begin{array}{l}\text { Typha, Eichhornia, Brachiaria, Pontederia and } \\
\text { Salvinia }\end{array}$ \\
\hline $\begin{array}{l}\text { Lateral lagoon B } \\
\text { (FPB) }\end{array}$ & $22^{\circ} 36^{\prime} 56.5^{\prime \prime} \mathrm{S} / 52^{\circ} 09^{\prime} 47.3^{\prime \prime} \mathrm{W}$ & 0.024 & $\begin{array}{l}\text { Eichhornia, Brachiaria, Pontederia, Salvinia, } \\
\text { Pistia, Egeria and Nymphaea }\end{array}$ \\
\hline $\begin{array}{l}\text { Lateral lagoon } \mathrm{C} \\
\text { (FPC) }\end{array}$ & $22^{\circ} 37^{\prime} 28,9^{\prime \prime} \mathrm{S} / 52^{\circ} 09^{\prime} 21.1^{\prime \prime} \mathrm{W}$ & 0.721 & $\begin{array}{l}\text { Eichhornia, Brachiaria, Pontederia, Salvinia and } \\
\text { Egeria }\end{array}$ \\
\hline $\begin{array}{l}\text { Paranapanema } \\
\text { River Bank (PR) }\end{array}$ & $22^{\circ} 37^{\prime} 51.6^{\prime \prime} \mathrm{S} / 52^{\circ} 09^{\prime} 30.5^{\prime \prime} \mathrm{W}$ & - & $\begin{array}{l}\text { Tipha, Eichhornia, Brachiaria, Pontederia, } \\
\text { Salvinia and Pistia }\end{array}$ \\
\hline $\begin{array}{l}\text { Lateral lagoon D } \\
\text { (FPD) }\end{array}$ & $22^{\circ} 38^{\prime} 22.0^{\prime \prime} \mathrm{S} / 52^{\circ} 09^{\prime} 29.0^{\prime \prime} \mathrm{W}$ & 0.063 & $\begin{array}{l}\text { Eichhornia, Brachiaria, Pontederia, Salvinia, } \\
\text { Pistia and Nymphaea }\end{array}$ \\
\hline
\end{tabular}

Small fish were sampled with a net of $7.5 \mathrm{~m}^{2}$ $(1.5 \times 5 \mathrm{~m} ; 0.3 \mathrm{~cm}$ of mesh size $)$. In each point $/$ period five manual throws were performed towards to the aquatic macrophyte stands and in the limnetic zone.

In the laboratory, the organisms were transferred to ethanol $70 \%$ for permanent storage. Voucher specimens are deposited in the Freshwater Fish Collection of the Department of Zoology, UNESP/Botucatu.

The biometry of the collected organisms was obtained through measurements of weigh (biomass in g; $0.01 \mathrm{~g}$ accuracy) and length (caliper, $0.1 \mathrm{~mm}$ ) - standard (except for Gymnotiformes and Synbranchiformes) and total.

For taxonomical identification of the fish species it was used specialized literature (Britsk, 1972; Britsk et al., 1986,
1999; Reis et al., 2003; Nelson, 2006; Graça and Pavanelli, 2007) and the scientific collections of the UNESP/São José do Rio Preto) and University of São Paulo Museum of Zoology (MZUSP) were also consulted.

Numerical richness, abundance and biomass were calculated for the communities, while the Index of Importance (Nataragam and Jhingian, 1961, apud Beaumord and Petrere Junior, 1994) was calculated for each species. The Shannon index was calculated to estimate the fish assemblage diversity of each lagoon for the distinct sampling periods. This index is widely used in analyses of communities structure (Magurran, 2004).

In order to describe the feeding preference of $C$. kelberi, its diet was determined through stomach content analysis. 
The items were identified under a stereoscopic microscope and microscope, trying to attain the most detailed taxonomic level.

The mean values of the community variables were calculated to synthesize the information and facilitate the identification of patterns. The data were grouped by sampling year. The representativeness of the means was assumed based on the normal data distribution (Shapiro-Wilk's W test) (Underwood, 1997; Statsoft, 2001), after previously standardization $\left(\log _{\mathrm{x}}+1\right)$.

Finally, a one-way ANOVA test was performed to detect differences among periods. When differences were detected, the Tukey test was applied to determine the level of significance (Underwood, 1997). It was considered significant difference values of $\mathrm{p}<0.05$ (Underwood, 1997), which were mentioned in the results. The analyses were performed using StatisticaTM 6.0 software (Statsoft, 2001).

\section{Results}

A total of 4,693 fish, belonging to 43 species was sampled between 2004 and 2009 (Table 2). The assemblages were primarily composed by small-size species, due to the chosen methodology. The order Characiformes was the most abundant, totalizing $95.4 \%$ of the individuals, followed by Perciformes, $2.5 \%$, and Siluriformes, $1.2 \%$. Other orders represented only $0.9 \%$ of the individuals.

In terms of Species Importance, the main species was Hemigrammus marginatus Ellis, 1911, which represented about $37 \%$ of the total captures. Other abundant species were Hyphessobrycon eques (Steindachner, 1882), Bryconamericus stramineus Eigenmann, 1908 and Serrapinnus notomelas (Eigenmann, 1915) for Characiformes; Crenicichla britskii Kullander, 1982 for Perciformes; Hypostomus ancistroides (Ihering, 1911) for Siluriformes and Gymnotus sylvius Albert \& Fernandes-Matioli, 1999 for Gymnotiformes.

A total of 899 individuals (21 species) were captured in the period that preceded the introduction of $C$. kelberi (before), while 3,994 individuals (43 species) were caught in all subsequent periods. Thirty-seven individuals of C. kelberi were captured along the study.

There were no differences between the fish richness if compared the periods before and after the introduction ( $p=0.86$; Figure 2). The fish richness during the year of 2008 showed a remarkable decreasing $(\mathrm{p}=0.03)$. However, this fact is probably not related to the Cichla introduction, because the number of caught individuals of this species during the mentioned period was low.

There were no difference between the fish abundance before and after the introduction ( $\mathrm{p}=0.55$; Figure 3 ). It was verified a decrease in the fish abundance when there was an increase in the Cichla abundance. Posterior to the reduction of Cichla, the assemblage abundance was reestablished. The species H. marginatus, H. eques and C. britskii exhibited higher decrease in abundance when the number of Cichla specimens was elevated. Other observed particularity is that most Cichla individuals were sampled in the lateral lagoon with higher fish abundance (FPA).
The same pattern was observed in terms of fish biomass. During the increase of Cichla population, the fish biomass decreased; but the weight just reestablished when Cichla abundance reduced. There was no significantly difference between the fish biomass before and after the introduction $(\mathrm{p}=0.677$; Figure 4).

The introduction of Cichla did not interfere in the mean length of fish ( $\mathrm{p}=0.83$; Table 2$)$. The sampled species

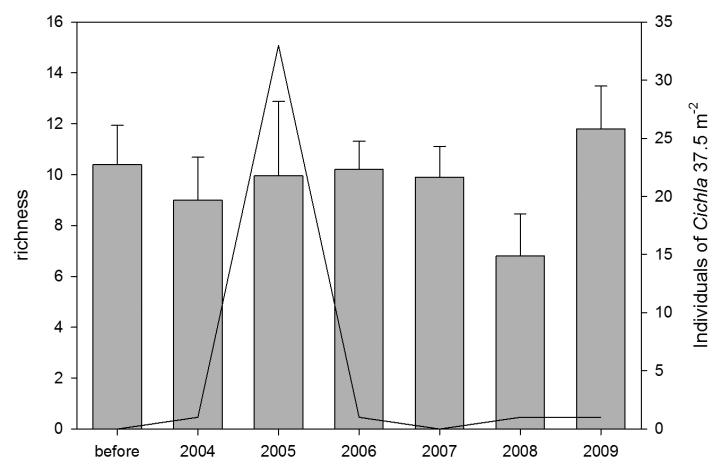

Figure 2. Mean value (and standard deviation) of species richness at the different sampling periods (gray bars) and density of Cichla (continuous line) $\left(37.5 \mathrm{~m}^{2}\right.$ of net $=$ sampling effort).

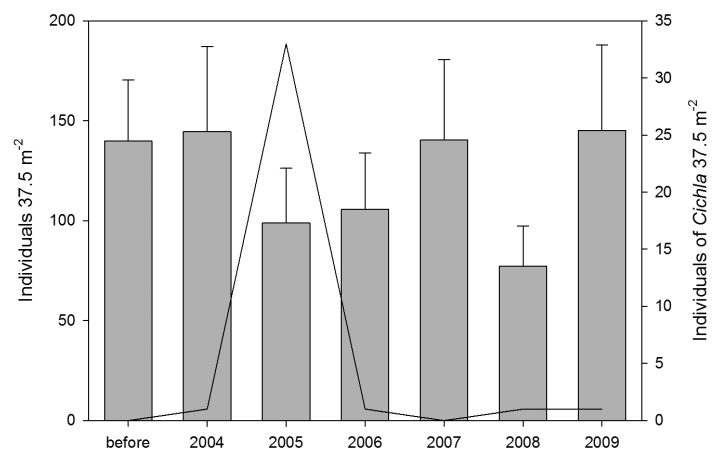

Figure 3. Mean value (and standard deviation) of absolute abundance of the ichthyofauna at the different sampling periods (gray bars) and density of Cichla (continuous line) $\left(37.5 \mathrm{~m}^{2}\right.$ of net $=$ sampling effort $)$

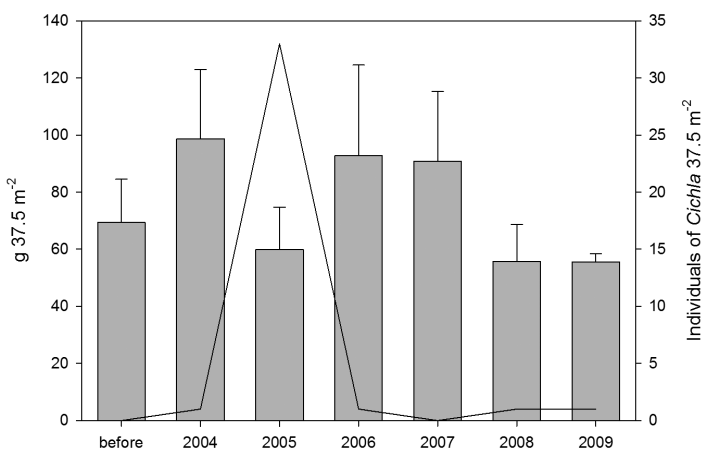

Figure 4. Mean value (and standard deviation) of biomass of the ichthyofauna at the different sampling periods (gray bars) and density of Cichla (continuous line) $\left(37.5 \mathrm{~m}^{2}\right.$ of net $=$ sampling effort $)$. 
Table 2. List of taxa identified in Rosana Reservoir during the study and the mean length (L) of the specimens, before and after the introduction of Cichla kelberi.

\begin{tabular}{|c|c|c|c|}
\hline Taxon & & L before & L after \\
\hline Order Characiformes & Family & & \\
\hline Astyanax altiparanae Garutti and Britski, 2000 & Characidae & 25 & 25.6 \\
\hline Acestrorhynchus lacustris (Lütken, 1875) & Acestrorhynchidae & - & 16 \\
\hline Apareiodon piracicabae (Eigenmann, 1907) & Parodontidae & 21 & 16.7 \\
\hline Aphyocharax anisitsi Eigenmann and Kennedy, 1903 & Characidae & 18 & 18.2 \\
\hline Bryconamericus stramineus Eigenmann, 1908 & Characidae & 23 & 22.1 \\
\hline Cyphocharax modestus (Fernández-Yépez, 1948) & Curimatidae & 20 & 15.4 \\
\hline Galeocharax knerii (Steindachner, 1875) & Characidae & - & 31 \\
\hline Hemigrammus marginatus Ellis, 1911 & Characidae & 18 & 17.8 \\
\hline Hoplias malabaricus (Bloch, 1794) & Erythrinidae & 74 & 73 \\
\hline Hyphessobrycon eques (Steindachner, 1882) & Characidae & 17 & 16.5 \\
\hline Leporinus friderici (Bloch, 1794) & Anostomidae & 32 & 32.8 \\
\hline Leporinus octofasciatus Steindachner, 1915 & Anostomidae & - & 20 \\
\hline Leporinus striatus Kner, 1858 & Anostomidae & 30 & 29.5 \\
\hline Metynnis lippincottianus (Cope, 1870) & Characidae & 14 & 14.3 \\
\hline Moenkhausia intermedia Eigenmann, 1908 & Characidae & 16 & 16.3 \\
\hline Myleus tiete (Eigenmann and Norris, 1900) & Characidae & - & 16 \\
\hline Oligosarcus pintoi Amaral Campos, 1945 & Characidae & - & 22 \\
\hline Roeboides descalvadensis Fowler, 1932 & Characidae & 28 & 28.5 \\
\hline Schizodon nasutus Kner, 1858 & Anostomidae & 28 & 28.7 \\
\hline Serrapinnus notomelas (Eigenmann, 1915) & Characidae & 19 & 19 \\
\hline Serrasalmus maculatus Kner, 1858 & Characidae & 16 & 15.9 \\
\hline Serrasalmus marginatus Valenciennes, 1836 & Characidae & - & 22 \\
\hline $\begin{array}{l}\text { Steindachnerina brevipinna } \\
\text { (Eigenmann and Eigenmann, 1889) }\end{array}$ & Curimatidae & - & 30 \\
\hline \multicolumn{4}{|l|}{ Order Gymnotiformes } \\
\hline Eigenmannia trilineata López and Castello, 1966 & Sternopygidae & - & 47 \\
\hline Eigenmannia virescens (Valenciennes, 1842) & Sternopygidae & - & 100 \\
\hline Gymnotus sylvius Albert \& Fernandes-Matioli, 1999 & Gymnotidae & 47 & 48.6 \\
\hline Rhamphichthys hahni (Meinken, 1937) & Rhamphichthyidae & - & 28 \\
\hline \multicolumn{4}{|l|}{ Order Siluriformes } \\
\hline Hypostomus ancistroides (Ihering, 1911) & Loricariidae & 19 & 20.3 \\
\hline Hypostomus sp. 1 & Loricariidae & - & 15 \\
\hline Hypostomus sp. 2 & Loricariidae & - & 28 \\
\hline Loricariichthys platymetopon Isbrücker and Nijssen, 1979 & Loricariidae & - & 24 \\
\hline Trachelyopterus galeatus (Linnaeus, 1766) & Auchenipteridae & - & 61 \\
\hline Pimelodus maculatus Lacepède, 1803 & Pimelodidae & - & 28 \\
\hline Rhamdia quelen (Quoy and Gaimard, 1824) & Heptapteridae & - & 38 \\
\hline \multicolumn{4}{|l|}{ Order Perciformes } \\
\hline Cichla kelberi Spix and Agassiz, 1831 & Cichlidae & - & 32 \\
\hline Cichlasoma paranaense Kullander, 1983 & Cichlidae & 29 & 27.3 \\
\hline Crenicichla britskii Kullander, 1982 & Cichlidae & 25 & 24.6 \\
\hline Crenicichla haroldoi Luengo and Britski, 1974 & Cichlidae & - & 19 \\
\hline Crenicichla jaguarensisHaseman, 1911 & Cichlidae & - & 28 \\
\hline Satanoperca pappaterra $($ Heckel, 1840) & Cichlidae & 17 & 18.5 \\
\hline \multicolumn{4}{|l|}{ Order Synbranchiformes } \\
\hline Synbranchus marmoratus Bloch, 1795 & Synbranchidae & - & 130 \\
\hline \multicolumn{4}{|l|}{ Order Cyprinidontiformes } \\
\hline Phalloceros harpagus Lucinda, 2008 & Poeciliidae & - & 35 \\
\hline \multicolumn{4}{|l|}{ Order Rajiformes } \\
\hline Potamotrygon motoro (Müller and Henle, 1841) & Potamotrygonidae & * & * \\
\hline
\end{tabular}

*Missing data. 
showed similar size before and after the introduction, even during the period when Cichla abundance was high.

The fish assemblage composition did not change after Cichla introduction. There was the predominance of Characiformes, followed by Perciformes and Siluriformes in all periods. Characiformes is more abundant in the lagoons, while Perciformes, Siluriformes and Gymnotiformes are more important in the river channel. The unique difference was seen when the Cichla abundance raised, the predominance of Characiformes was lower, due to the decrease of $H$. marginatus. The Siluriformes was the order that increased most after the introduction, but this is probably associated with the higher number samplings, as no species of this order was predominant after the introduction. The relative abundance among the taxonomic orders is presented in Figure 5, for the whole sampling period.

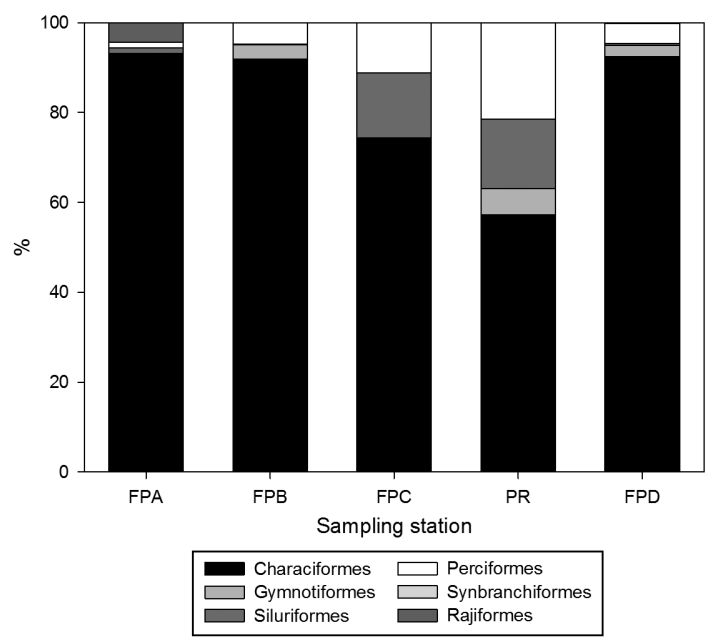

Figure 5. Relative abundance of the ichthyofauna at the different sampling stations considering the whole sampling period. $\mathrm{PR}=$ Paranapanema River; FPA = lagoon originated by the flood of mining digging; FPB and FPD = natural lagoons located inside a preservation area; $\mathrm{FPC}=$ lagoon under influence of agriculture and cattle breeding.

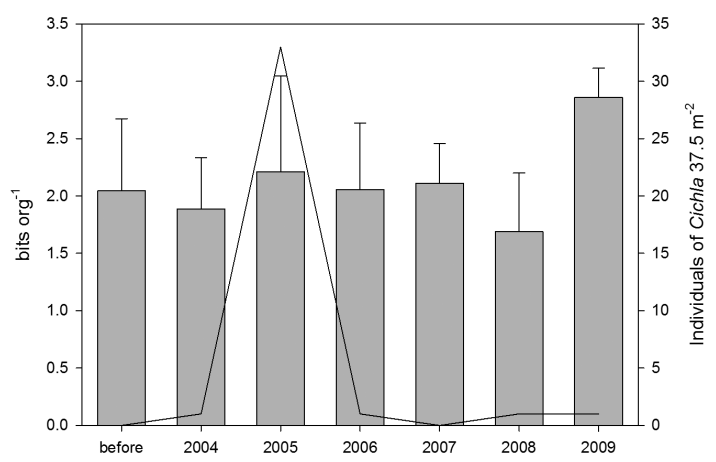

Figure 6. Shannon diversity index (H') of the ichthyofauna at the different sampling periods (gray bars) and density of Cichla (continuous line) $\left(37.5 \mathrm{~m}^{2}\right.$ of net $=$ sampling effort $)$.
The fish diversity was higher before the introduction of Cichla ( $\mathrm{p}=0.04$; Figure 6). The number of the predominant species (H. marginatus, H. eques and C. britskii) decreased, what allowed other species of minor importance to increase in abundance, such as Cyphocharax modestus (Fernández-Yépez, 1948), Roeboides descalvadensis Fowler, 1932 and Aphyocharax anisitisi Eigenmann and Kennedy, 1903.

Finally, aquatic insects were the main feeding item of C. kelberi, followed by fish of the sub-family Tetragonopterinae. Cannibalism was recorded during the whole study period. Detailed analyses of the assemblages fish diet is provided by Ferrareze et al. (2015).

\section{Discussion}

The probability of a given species to become a well succeeded invader is generally low, even rare. When the event is rare, the prediction of the facts becomes hard, because it depends not only on the prediction accuracy, but also on the frequency that the event occurs (Colautti and MacIsaac, 2004; Brasher et al., 2006).

When a species is introduced in a region, only a certain number of individuals will survive and most of them will fail to succeed. Thus, the damage of non native species can just be evaluated after the real introduction, because no one can be completely sure if the establishment of it will occur (Colautti and MacIsaac, 2004; Jeschke and Strayer, 2006).

In the Rosana Reservoir case, the results showed that C. kelberi seems not to have had a significant effect on the ichthyofauna, as predicted by Pelicice and Agostinho et al. (2008).

Our results did not show statistically differences in the ichthyofauna structure after the introduction of C. kelberi in the reservoir. The diversity values even improved, after the introduction. This fact happened due to the decrease of the number of the most abundant species, diminishing the competition and allowing the increase of the abundance of some species with minor importance as C. modestus, R. descalvadensis and A. anisitisi. However, some tendencies of disturb could be observed, indicating that this species can interfere in the local ichthyofauna. According to McKinney (2006), when a high number of predators found an opportunity to spread, they can produce pronounced changes on the local fish community, and this possibility cannot be neglected.

Firstly, it is interesting to note that a high number of Cichla was found in the lagoon with the higher abundance of small size fish. Second, when the Cichla abundance was high, the abundance of the main species and the fish biomass decreased, corroborating with the initial study of the species impact in the Rosana Reservoir (Pelicice and Agostinho, 2009).

The results allowed to conclude that the introduction of Cichla kelberi in the reservoir is in the phase 3 (sensu Colautti and MacIsaac, 2004). In this phase, the specie can survive and reproduce in the new environment; however it 
is not established, disseminated and dominant. So, probably Cichla is still not well established in the reservoir, and the initial introduction effects were buffered by the plasticity of the fish along the time (Ruesink, 2005).

It is difficult to point out the reasons to explain why Cichla is not properly established, but it could be related with the feeding competition, high rate of cannibalism and the extensive presence of aquatic macrophytes in the reservoir.

Juveniles of Cichla kelberi, as several other Neotropical fish species, uses the aquatic insects as the main feeding item and some of this species are highly specialized to capture their prey, such as Gymnotus and Crenicichla. Another fact is that the Tetragonipterinae, used by Cichla, are also an important feeding item of Serrasalmus maculatus Kner, 1858 and Hoplias malabaricus (Bloch, 1794) (Ferrareze et al., 2015).

The feeding competition can reduce the prey availability and raise the cannibalism (Novaes et al., 2004). The cannibalism also can reduce the chances of surviving of a non native fish in a new environment. The drastic reduction of the introduced population, reduce the genetic and morphologic variability, as well as the reproduction success (Wootton, 1990; Santos et al., 2001).

Other important fact preventing Cichla to become dominant in the reservoir is the presence of macrophytes, as previously mentioned. The plant structures offer an ideal environment for refuge and shelter for prey, mainly for small sized fish, what makes harder their capture by predators (Rozas and Odum, 1988; Schriver et al., 1995; Ferrareze and Nogueira, 2011).

Therefore, the results showed that Cichla didn't impair the whole ichthyofauna assemblages of a Neotropical reservoir and changed the fish assemblage structure immediately after its introduction (Ferrareze and Nogueira, 2011). But, the real problems about the introduction only will be determined, when the process reaches the next steps (4 and 5). When the species will reach these steps cannot be determined (Colautti and MacIsaac, 2004).

The decrease in the ichthyofauna attributes verified during the year of 2008, such as low richness, abundance, biomass and diversity is probably resulted of the irregular climate verified in that year. There were strong rains in the wet period (from January to March) and a long dry season in the winter/spring of 2008 (no published data). These changes reflected on the ichthyofauna, promoting the decrease of the ecological attributes, as verified in other studies (Gafny et al., 2000; Barrella and Petrere Junior 2003).

Despite of the inconclusive results to support the hypothesis that Cichla kelberi has caused a significant negative impact on the ichthyofauna of Rosana Reservoir, the role of non native species in the local fish fauna should be a major concern of aquatic ecology scientists and environmental managers. The continuous monitoring of non-native species is imperative, because in several cases, the introduction reach the final phase, promoting drastic changes in the local ichthyofauna (Zaret and Paine, 1973;
Kaufman, 1992; Macchi et al., 1999). Additionally, it must be considered that the impacts caused by colonization of this undesirable species can be magnified by complex processes, usually correlated with other environmental disturb (Byers, 2002; Shea and Chesson, 2002), especially the negative effects of damming (Agostinho et al., 2007). Nevertheless, the assumptions cannot be totally pessimist, as the system has a natural resiliency that can minimize disturbances (Odum, 2004).

\section{Acknowledgements}

The authors are grateful to the CNPq for the scholarship conceived to the first author; to Dr Francisco Langeani Neto for helping with fish identification; and to Duke Energy International Geração Paranapanema and Fundação do Instituto de Biociências for the financial and administrative support.

\section{References}

AGOSTINHO, A.A., PELICICE, F.M. and GOMES, L.C., 2008. Dams and the fish fauna of the Neotropical region: impacts and management related to diversity and fisheries. Brazilian Journal of Biology $=$ Revista Brasileira de Biologia, vol. 68, no. 4, suppl., pp. 1119-1132. http://dx.doi.org/10.1590/S151969842008000500019. PMid:19197482.

AGOstinHO, A.A., PELICICE, F.M., PETRY, A.C., GOMES, L.C. and JULIO JUNIOR, H.F., 2007. Fish diversity in the upper Paraná River basin: habitats, fisheries, management and conservation. Aquatic Ecosystem Health \& Management, vol. 10, no. 2, pp. 174-186. http://dx.doi.org/10.1080/14634980701341719.

AHEARN, D.S., SHEIBLEY, R.W. and DAHLGREN, R.A., 2005. Effects of river regulation on water quality in the Lower Mokelumne River, California. River Research and Applications, vol. 21, no. 6, pp. 651-670. http://dx.doi.org/10.1002/rra.853.

BARRELLA, W. and PETRERE JUNIOR, M., 2003. Fish community alterations due to pollution and damming in Tietê and Paranapanema Rivers (Brazil). River Research and Applications, vol. 19, no. 1, pp. 59-76. http://dx.doi.org/10.1002/rra.697.

BEAUMORD, A.C. and PETRERE JUNIOR, M., 1994. Comunidades de peces del Rio Manso, Chapada dos Guimarães, MT, Brasil. Acta Biologica De Venezuela, vol. 15, no. 2, pp. 21-35.

BRASHER, A.M.D., LUTON, C.D., GOODBRED, S.L. and WOLFF, R.H., 2006. Invasion patterns along elevation and urbanization gradients in Hawaiian stream. Transactions of the American Fisheries Society, vol. 135, no. 4, pp. 1109-1129. http:// dx.doi.org/10.1577/T05-083.1.

BRITSK, H.A., 1972. Peixes de água doce do Estado de São Paulo. In: COMISSÃO INTERESTADUAL DA BACIA PARANÁ-URUGUAI, ed. Poluição e piscicultura. São Paulo: CIBPU, pp. 79-108.

BRITSK, H.A., SATO, Y. and ROSA, A.B.S., 1986. Manual de identificação de peixes da região de Três Marias (com chaves de identificação para os peixes da bacia do São Francisco). Brasília: Câmara dos Deputados/CODEVASF, 143 p.

BRITSK, H.A., SILIMON, K.Z.S. and LOPES, S.L., 1999. Peixes do Pantanal: manual de identificação. Brasília: EMBRAPA. 184 p. 
BYERS, J.E., 2002. Impact of non-indigenous species on natives enhanced by anthropogenic alteration of selection regimes. Oikos, vol. 97 , no. 3 , pp. 449-458. http://dx.doi.org/10.1034/j.16000706.2002.970316.x.

CASATTI, L., MENDES, H.F. and FERREIRA, K.M., 2003. Aquatic macrophytes as feeding site for small fish in the Rosana Reservoir, Paranapanema River, Southeastern Brazil. Brazilian Journal of Biology $=$ Revista Brasileira de Biologia, vol. 63, no. 2, pp. 1-8. http://dx.doi.org/10.1590/S1519-69842003000200006.

COLAUTTI, R.I. and MACISAAC, H.J., 2004. A neutral terminology to define "invasive" species. Diversity \& Distributions, vol. 10, no. 2, pp. 135-141. http://dx.doi.org/10.1111/j.1366-9516.2004.00061.x.

FERRAREZE, M. and NOGUEIRA, M.G., 2011. Importance of lateral lagoons for the ichthyofauna in a large tropical reservoir. Brazilian Journal of Biology $=$ Revista Brasileira de Biologia, vol. 71, no. 4, pp. 807-820. http://dx.doi.org/10.1590/S151969842011000500002 .

FERRAREZE, M., NOGUEIRA, M.G. and CASATTI, L., 2015. Difference of ichthyofauna feeding habits among lateral lagoons and river channel in a large reservoir. Brazilian Journal of Biology $=$ Revista Brasileira de Biologia, vol. 75, no. 2, pp. 380-390. http://dx.doi.org/10.1590/1519-6984.14713. PMid:26132022.

FERRAREZE, M., NOGUEIRA, M.G. and SARTOTI, L.P., 2014. Limnology of lateral lagoons in a tropical reservoir (SE Brazil) - spatial and temporal variability. Acta Scientiarum, vol. 36, no. 3, pp. 197-207.

GAFNY, S., GOREN, M. and GASITH, A., 2000. Habitat condition and fish assemblage structure in a coastal Mediterranean stream (Yarquon, Israel) receiving domestic effluent. Hydrobiologia, vol. 422-423, pp. 319-330. http://dx.doi.org/10.1023/A:1017040017238.

GIDO, K.B. and BROWN, J.H., 1999. Invasion of North American drainages by alien fish species. Freshwater Biology, vol. 42, no. 2, pp. 387-399. http://dx.doi.org/10.1046/j.1365-2427.1999.444490.x.

GODINHO, A.L., FONSECA, M.T. and ARAUJO, L.M., 1994. The ecology of predator fish introductions: the case of Rio Doce valley lakes. In: R.M. PINTO-COELHO, A. GIANI and E. VON SPERLING, eds. Ecology and human impact on lakes and reservoirs in Minas Gerais, with special reference to future development and management strategies. Belo Horizonte: Segrac, pp. 77-83.

GRAÇA, W.J. and PAVANELLI, C.S., 2007. Peixes da planície de inundação do alto rio Paraná e áreas adjacentes. Maringá: EDUEM, $241 \mathrm{p}$.

HAN, M., FUKUSHIMA, M. and FUKUSHIMA, T., 2008. A spatial linkage between dams and non-native fish species in Hokkaido, Japan. Ecology Freshwater Fish, vol. 17, no. 3, pp. 416-424. http://dx.doi.org/10.1111/j.1600-0633.2008.00294.x.

HOLMQUIST, J.G., SCHMIDT-GENGENBACH, J.M. and YOSHIOKA, B.B., 1998. High dams and marine-freshwater linkages: effects on native and introduced fauna in the Caribbean. Conservation Biology, vol. 12, no. 3, pp. 621-630. http://dx.doi. org/10.1046/j.1523-1739.1998.96427.x.

JESCHKE, J.M. and STRAYER, D.L., 2006. Determinants of vertebrate invasion success in Europe and North America. Global Change Biology, vol. 12, no. 9, pp. 1608-1619. http://dx.doi. org/10.1111/j.1365-2486.2006.01213.x.

KAUFMAN, L., 1992. Catastrophic change in species-rich freshwater ecosystems: the lessons of Lake Victoria. Bioscience, vol. 42, no. 11, pp. 846-858. http://dx.doi.org/10.2307/1312084.
KULLANDER, S.O. and FERREIRA, E.J.G., 2006. A review of the South American cichlid genus Cichla, with descriptions of nine new species (Teleostei: Cichlidae). Ichthyological Exploration of Freshwaters, vol. 17, pp. 289-398.

LATINI, A.O. and PETRERE JUNIOR, M., 2004. Reduction of a native fish fauna by alien species: an example from Brazilian freshwater tropical lakes. Fisheries Management and Ecology, vol. 11, no. 2, pp. 71-79. http://dx.doi.org/10.1046/j.13652400.2003.00372.x

LEPRIEUR, F., HICKEY, M.A., ARBUCKLE, C.J., CLOSS, G.P., BROSSE, S. and TOWNSEND, C.R., 2006. Hydrological disturbance benefits a native fish at the expense of an exotic fish. Journal of Applied Ecology, vol. 43, no. 5, pp. 930-939. http:// dx.doi.org/10.1111/j.1365-2664.2006.01201.x.

LIGHT, T. and MARCHETTI, M.P., 2007. Distinguishing between invasions and habitat changes as drivers of diversity loss among California's freshwater fishes. Conservation Biology, vol. 21, no. 2, pp. 434-446. http://dx.doi.org/10.1111/j.1523-1739.2006.00643.x. PMid:17391193.

MACCHI, P.J., CUSSAC, V.E., ALONSO, M.F. and DENEGRI, M.A., 1999. Predation relationships between introduced salmonids and the native fish fauna in lakes and reservoirs in northern Patagonia. Ecology Freshwater Fish, vol. 8, no. 4, pp. 227-236. http://dx.doi.org/10.1111/j.1600-0633.1999.tb00074.x.

MAGURRAN, A.E., 2004. Measuring biological diversity. Oxford: Blackwell Publishing. 256 p.

MARCHETTI, M.P., LOCKWOOD, J.L. and LIGHT, T., 2006. Effects of urbanization on California's fish diversity: differentiation, homogenization and the influence of spatial scale. Biological Conservation, vol. 127, no. 3, pp. 310-318. http:// dx.doi.org/10.1016/j.biocon.2005.04.025.

MCKINNEY, M.L., 2006. Urbanization as a major cause of biotic homogenization. Biological Conservation, vol. 127, no. 3, pp. 247-260. http://dx.doi.org/10.1016/j.biocon.2005.09.005.

NELSON, J.S., 2006. Fishes of the world. 4th ed. New York: John Wiley \& Sons. 600 p.

NOGUEIRA, M.G., JORCIN, A., VIANNA, N.C. and BRITTO, Y.C.T., 2006. Reservatórios em cascata e os efeitos na limnologia e organização das comunidades bióticas (fitoplâncton, zooplâncton e zoobentos) - um estudo de caso no rio Paranapanema. In: M.G. NOGUEIRA, R. HENRY and A. JORCIN, eds. Ecologias de reservatórios: impactos potenciais, ações de manejo e sistema em cascata. São Carlos: Rima, chap. 4, pp. 83-125.

NOVAES, J.L.C., CARAMASCHI, E.P. and WINEMILLER, K.O., 2004. Feeding of Cichla monoculus Spix, 1829 (Teleostei, Cichlidae) during and after reservoir formation in the Tocantins River, central Brazil. Acta Limnologica Brasiliensia, vol. 16, no. 1 , pp. 41-49.

ODUM, E.P., 2004. Fundamentals of ecology. 5th ed. Belmont: Brooks Cole. 624 p.

OLDEN, J.D. and POFF, N.L., 2004. Ecological processes driving biotic homogenization: testing a mechanistic model using fish faunas. Ecology, vol. 85, no. 7, pp. 1867-1875. http://dx.doi. org/10.1890/03-3131.

PELICICE, F.M. and AGOSTINHO, A.A., 2009. Fish fauna destruction after the introduction of a non-native predator (Cichla kelberi) in a Neotropical Reservoir. Biological Invasions, vol. 11, no. 8, pp. 1789-1801. http://dx.doi.org/10.1007/s10530-008-9358-3. 
PELICICE, F.M., AGOSTINHO, A.A. and THOMAZ, S.M., 2005. Fish assemblages associated with Egeria in a tropical reservoir: investigating the effects of plant biomass and diel period. Acta Oecologica, vol. 27, no. 1, pp. 9-16. http://dx.doi.org/10.1016/j. actao.2004.08.004.

PRINGLE, C.M., FREEMAN, M.C. and FREEMAN, B.J., 2000. Regional effects of hydrologic alterations on riverine macrobiota in the new world: tropical-temperate comparisons. Bioscience, vol. 9, no. 9, pp. 807-823. http://dx.doi.org/10.1641/00063568(2000)050[0807:REOHAO]2.0.CO;2.

REIS, R.E., KULLANDER, S.O. and FERRARIS, C.J., 2003. Check list $f$ the freshwater fish of South and Central America. Porto Alegre: EDIPUCRS. 742 p.

ROZAS, L.P. and ODUM, W.E., 1988. Occupation of submerged aquatic vegetation by fish: testing the roles of food and refuge. Oecologia, vol. 77, no. 1, pp. 101-106. http://dx.doi.org/10.1007/ BF00380932.

RUESINK, J.L., 2005. Global analysis of factors affecting the outcome of freshwater fish introductions. Conservation Biology, vol. 19 , no. 6 , pp. 1883-1893. http://dx.doi.org/10.1111/j.15231739.2005.00267.x-i1.

SANTOS, G.B., MAIA-BARBOSA, P.M., VIEIRA, F. and LOPEZ, C.M., 1994. Fish and zooplankton community structure in reservoirs of southeastern Brazil: effects of the introduction of exotic predatory fish. In: R.M. PINTO-COELHO, A. GIANI and E. VON SPERLING, eds. Ecology and human impact on lakes and reservoirs in Minas Gerais, with special reference to future development and management strategies. Belo Horizonte: Segrac, pp. 115-132.

SANTOS, L.N., GONZALES, A.F. and ARAÚJO, F.G., 2001. Dieta do tucunaré-amarelo Cichla monoculus (Bloch and Schneider) (Osteichthyes, Cichlidae), no reservatório de Lajes, Rio de Janeiro, Brasil. Revista Brasileira de Zoologia, vol. 18, pp. 191-204. http:// dx.doi.org/10.1590/S0101-81752001000500015.
SCHRIVER, P., BOGESTRAND, J., JEPPESEN, E. and SONDERGAARD, M., 1995. Impact of submerge macrophytes on fish-zooplankton-phytoplankton interactions: large scale enclosure experiments in a shallow eutrophic lake. Freshwater Biology, vol. 33, no. 2, pp. 255-270. http://dx.doi.org/10.1111/j.1365-2427.1995. tb01166.x.

SHEA, K. and CHESSON, P., 2002. Community ecology theory as a framework for biological invasions. Trends in Ecology \& Evolution, vol. 17, no. 4, pp. 170-176. http://dx.doi.org/10.1016/ S0169-5347(02)02495-3.

SIMBERLOFF, D., 2003. Confronting introduced species: a form of xenophobia? Biological Invasions, vol. 5, no. 3, pp. 179-192. http://dx.doi.org/10.1023/A:1026164419010.

SMITH, K.G., 2006. Patterns of nonindigenous herpetofaunal richness and biotic homogenization among Florida counties. Biological Conservation, vol. 127, no. 3, pp. 327-335. http:// dx.doi.org/10.1016/j.biocon.2005.04.026.

STATSOFT, 2001. Statistica (data analysis software system). Version 6. [software]. Tulsa: Statsoft Inc.

STOHLGREN, T.J., BARNETT, D., FLATHER, C., FULLER, P., PETERJOHN, B., KARTESZ, J. and MASTER, L.L., 2006. Species richness and patterns of invasion in plants, birds, and fishes in the United States. Biological Invasions, vol. 8, no. 3, pp. 427-447. http://dx.doi.org/10.1007/s10530-005-6422-0.

UNDERWOOD, A.J., 1997. Experiments in ecology: their logical design and interpretation using analysis of variance. London: Cambridge University Press, $432 \mathrm{p}$.

WOOTTON, R.J., 1990. Ecology of teleost fishes. London: Chapman and Hall. 404 p.

ZARET, T.M. and PAINE, R.T., 1973. Species Introduction in a Tropical Lake: A newly introduced piscivore can produce population changes in a wide range of trophic levels. Science, vol. 182 , no. 4111, pp. 449-455. http://dx.doi.org/10.1126/ science.182.4111.449. PMid:17832455. 